\title{
Proteomic Analysis of Lipid Droplets in Sesamum indicum
}

\author{
Satoshi Hamada ${ }^{1}$ Akihiro Kishikawa ${ }^{1}$ Motonobu Yoshida ${ }^{1,2}$
}

Published online: 29 May 2020

(c) The Author(s) 2020

\begin{abstract}
We attempted to identify the total proteome in sesame lipid droplets. Results from two-dimensional electrophoresis showed 139 protein spots in lipid droplet samples. Each spot was isolated, digested with trypsin, and applied to liquid chromatography-tandem mass spectrometry (Q-Tof Premier). As a result, 103 spots were identified. Although oleosin, caleosin, and steroleosin are known major components of the lipid droplet, many other proteins were also found in the lipid droplet. In addition to the three major proteins, TAG factor protein, glyceraldehyde-3-phosphate dehydrogenase, $\mathrm{F}_{1}$ ATPase, 70-kDa heat shock protein, seed maturation protein PM24, and 11S globulin precursor isoforms 3 and 4 were found in the lipid droplet. Three types of oleosins, 15-, 15.5-, and 17-kDa were present in the sesame lipid droplet, and the 15.5-kDa oleosin had high homology with oleosin from Coffea canephora. It has been shown by acid phosphatase treatment that oleosin proteins contain phosphate groups. Protein disulfide-isomerase 2 precursor, calreticulin-1, and BiP, which are known as marker proteins of the endoplasmic reticulum, were found as the components of the lipid droplet. Immunoconfocal microscopy was used to show that $11 \mathrm{~S}$ globulin precursor isoform 3 and 4 were indeed localized in the lipid droplet. The presence of $11 \mathrm{~S}$ globulin in the lipid droplets suggested a new mechanism for the lipid droplet formation.
\end{abstract}

Keywords Sesamum indicum $\cdot$ Lipid droplet formation $\cdot$ Sesame seed $\cdot$ Proteomics $\cdot$ Oleosin modification $\cdot$ Transportation

\begin{tabular}{|c|c|}
\hline \multicolumn{2}{|c|}{ Abbreviation } \\
\hline CBB & Coomassie brilliant blue \\
\hline СТАВ & Cetyl trimethyl ammonium bromide \\
\hline ER & Endoplasmic reticulum \\
\hline FITC & Fluorescein isothiocyanate \\
\hline LC-MS/MS & $\begin{array}{l}\text { Liquid chromatography-tandem mass } \\
\text { spectrometry }\end{array}$ \\
\hline PBS & Phosphate buffered saline \\
\hline SDS-PAGE & $\begin{array}{l}\text { Sodium dodecyl sulfate-polyacrylamide gel } \\
\text { electrophoresis }\end{array}$ \\
\hline TAG & Triacylglycerol \\
\hline
\end{tabular}

Satoshi Hamada and Akihiro Kishikawa have contributed equally to this work.

Part of this paper has been reported in a symposium of the Botanical Society of Japan held at Toyama University (2008).

Motonobu Yoshida

yoshida3m@gmail.com

1 Department of Agricultural Science, Kinki University, Nakamachi 3327-204, Nara 631-8505, Japan

2 Osaka University of Comprehensive Children Education, 6-4-26 Yusato, Higashisumiyoshi-ku, Osaka 546-0013, Japan

\section{Introduction}

The usage of biodiesel and bioethanol instead of petroleum resources has recently come to attention because these fuels have the potential to be less harmful to the environment. Oil crops, including sesame, are used as energy resources as well as crop resources [1]. Among these oil crops, sesame seeds are good energy resources because they contain high amounts of oleic acid, which can be converted to biodiesel with high efficiency. From this point of view, it is important to investigate the components or the formation mechanism of the lipid droplets, the oil storage organelle, of sesame seeds in more detail in order to obtain high productivity from sesame oil. It was shown previously that three proteins are key components of sesame lipid droplets [2, 3]. Oleosin is a major lipid droplet protein, with isoforms with molecular weights of 15-, 15.5-, and 17-kDa. Oleosin proteins function to block the fusion of lipid droplets. In addition, they are known to contain caleosin (molecular weight $27-\mathrm{kDa}$ ) that has a calcium-binding motif, and steroleosin (molecular weights 39- and 42-kDa) that retains sterol and NADPHbinding abilities. It has been suggested that these major proteins are synthesized in the endoplasmic reticulum (ER) and then incorporated into the lipid droplets on separation of the 
lipid droplets from the ER at the time of budding [4]. On the other hand, it has also been suggested that lipid droplet proteins may be transported to the droplet after formation of the droplet [5]. Moreover, there are several hypotheses concerning the formation of lipid droplets (Fig. 1, [6]). (1) Lipid droplets bud off toward the cytosol. (2) Lipid droplets are formed and leave behind a gap in the ER membrane, and afterwards the gap closes rapidly. (3) Lipid droplets form remodeling of the ER-derived bilayer to yield a monolayer covering the droplet. At present, the formation mechanism of lipid droplets and the transportation mechanisms of lipid droplet proteins are unclear. In these circumstances, we focused on the proteomics of lipid droplets to identify the full lipid droplet proteome and clarify the formation mechanism of lipid droplets. In the present study, numerous proteins were found as components of the lipid droplet. Protein disulfide-isomerase 2 precursor, calreticulin-1, and BiP, as a marker protein of the ER, were found in the lipid droplet [7]. Taking these results into consideration, we will discuss the mechanism of the lipid droplet formation.

\section{Materials and Methods}

\subsection{Plant Materials}

Sesame, Sesamum indicum, seeds (Acc. No. 800) were obtained from Toyama University. Toyama University is a sesame stock center in Japan. The Acc. No. of each variety has been registered there. Mature sesame seeds were grown, harvested at a field of Kinki University, and used to prepare lipid droplets.

\subsection{Isolation and Purification of Lipid Droplets}

Sesame seeds, $0.4 \mathrm{~g}$ were immersed for $30 \mathrm{~min}$ at $4{ }^{\circ} \mathrm{C}$ in $4 \mathrm{ml}$ of $0.6 \mathrm{M}$ sucrose $/ 10 \mathrm{mM} \mathrm{Na}_{2} \mathrm{HPO}_{4}-\mathrm{KH}_{2} \mathrm{PO}_{4}, \mathrm{pH}$ $7.5(\mathrm{~PB})$ and homogenized using a polytron homogenizer PT2100 (Kinematica AG, Luzern, Switzerland) at 22,000 rpm for $20 \mathrm{~s}$. as described previously [8]. The homogenates were passed through a $40 \mu \mathrm{m}$ filter. After filtration, the sample was placed at the bottom of a centrifuge tube, and the same volume of medium containing $0.4 \mathrm{M}$ sucrose/ PB was layered on top. The samples were centrifuged at $9000 \times g$ for $20 \mathrm{~min}$. After centrifugation, the top layer including lipid droplets was collected as sample I and placed at the bottom of a fresh centrifuge tube. The same volume of medium containing $0.2 \mathrm{M}$ sucrose/PB was layered on top. After centrifugation at $9000 \times g$ for $20 \mathrm{~min}$, the top layer including lipid droplets was collected as sample II and placed at the bottom of a fresh centrifuge tube, and the same volume of PB was layered on top. The samples were centrifuged again at $9000 \times g$ for $20 \mathrm{~min}$. The top layer including lipid droplets was prepared as sample III for focused proteomics analysis. In immunofluorescence experiments, part of sample II was used to examine the localization of $11 \mathrm{~S}$ globulin a native lipid droplets, and
Fig. 1 Models of lipid droplet formation. a triacylglycerols (TAGs) are deposited between the leaflets of the ER membrane. After reaching a critical size to form a lipid droplet, the TAG core buds off from the ER membrane. Lipid droplets are covered with a monolayer from the leaflet of the cytosol side of the ER membrane. b Lipid droplet formation is similar to model (a). However, lipid droplets are excised from the ER membrane, and both ER membrane leaflets contribute to the lipid droplet surface monolayer. c Inclusion of the TAG core in the membrane vesicle requires rearrangement of the leaflet of lumen side of the ER membrane
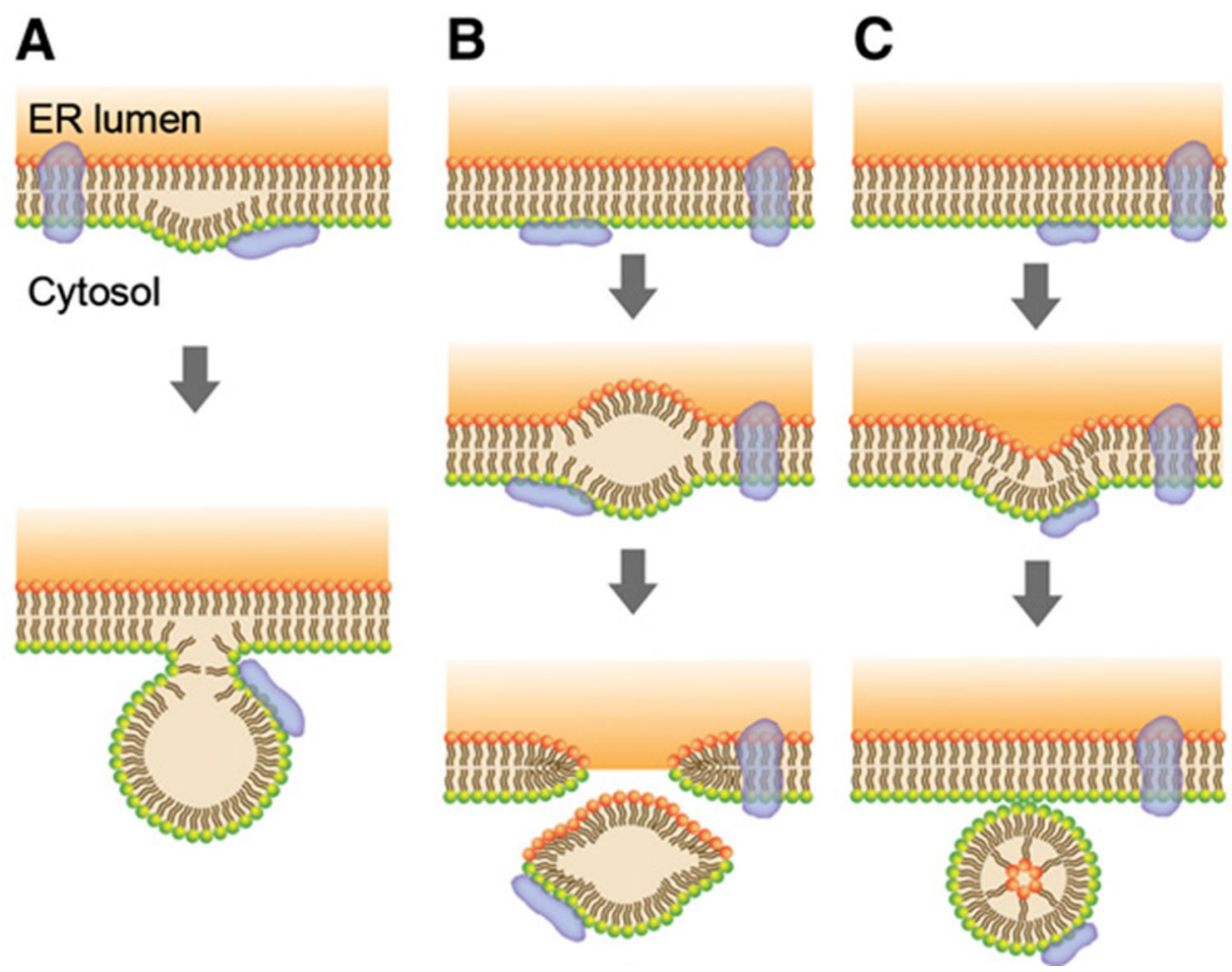
each sample was treated with four kinds of detergent, Triton X-100, Tween 20 , SDS or CTAB, at $0.5 \%$ final concentrations for $2 \mathrm{~h}$ at room temperature (RT).

\subsection{SDS-Polyacrylamide Gel Electrophoresis}

Samples were subjected to SDS-polyacrylamide gel electrophoresis (PAGE) with $12.5 \%$ acrylamide gels using the standard method [9]. After electrophoresis, the gel was stained with 2-D SILVER STAIN·II "DAIICHI" (Daiichi Pure Chemicals, Tokyo, Japan) or Coomassie brilliant blue (CBB).

\subsection{Two-Dimensional Electrophoresis}

Samples were solubilized with $200 \mu$ of sample buffer containing $8 \mathrm{M}$ urea, $50 \mathrm{mM}$ dithiothreitol (DTT), 2\% CHAPS, $0.001 \%$ bromophenol blue, $0.2 \%$ ampholine $\mathrm{pH} 3.5-10$ (GE Healthcare, Buckinghamshire, UK) and applied onto $11 \mathrm{~cm}$ IPG ReadyStrip 3-10 (Bio-Rad) and focused using a PROTEAN ${ }^{\circledR}$ IEF Cell (Bio-Rad). Strips were rehydrated for $12 \mathrm{~h}$ at $20^{\circ} \mathrm{C}$ in passive mode, and focused at $250 \mathrm{~V}$ for $15 \mathrm{~min}, 8000 \mathrm{~V}$ for $1 \mathrm{~h}$, and $8000 \mathrm{~V}$ for 35,000 V-h. Before second dimension electrophoresis, strips were kept at RT for $20 \mathrm{~min}$ in equilibration buffer I containing $6 \mathrm{M}$ urea, $2 \%$ SDS, 20\% glycerol, $0.375 \mathrm{M}$ Tris- $\mathrm{HCl}$, pH 8.8, 2\% DTT. Next, the strips were kept at RT for 10 min in equilibration buffer II containing $6 \mathrm{M}$ urea, 2\% SDS, 20\% glycerol, 0.375 $\mathrm{M}$ Tris- $\mathrm{HCl}, \mathrm{pH} 8.8,2.5 \%$ iodoacetamide. Second dimension electrophoresis was performed in SDS-PAGE with 12.5\% acrylamide, at a constant current of $6 \mathrm{~mA}$. The gels were stained with CBB. A part of sample II was treated with acid phosphatase from wheat germ $(230 \mu \mathrm{g}$, Nacalai Tesque, Kyoto, Japan) in $1100 \mu \mathrm{l} 10 \mathrm{mM}$ acetate buffer, $\mathrm{pH}$ 5.0, 0.1\% $\mathrm{NP}-40$ for $14 \mathrm{~h}$ at $40{ }^{\circ} \mathrm{C}$. The sample was applied onto $7 \mathrm{~cm}$ IPG ReadyStrip 3-10 and analyzed using the PROTEAN ${ }^{\circledR}$ IEF Cell.

\subsection{In-Gel Digestion}

Protein spots were cut out and washed with a destaining buffer containing $50 \% \mathrm{CH}_{3} \mathrm{CN}, 25 \mathrm{mM} \mathrm{NH}_{4} \mathrm{HCO}_{3}$ until CBB was completely removed. The gel spots were completely dehydrated with $100 \% \mathrm{CH}_{3} \mathrm{CN}$ and dried using a Micro Vac (Tomy, Tokyo, Japan). Protein digestion was carried out with $10 \mu \mathrm{g} / \mathrm{ml}$ trypsin solution (Promega) in $50 \mathrm{mM}$ $\mathrm{NH}_{4} \mathrm{HCO}_{3}$ for $16 \mathrm{~h}$ at $37^{\circ} \mathrm{C}$. Gel pieces were extracted twice with $50 \% \mathrm{CH}_{3} \mathrm{CN}, 5 \% \mathrm{HCOOH}$. Each extract was combined and dried to $5 \mu \mathrm{l}$ in the Micro Vac. One $\mu \mathrm{l}$ of $30 \% \mathrm{CH}_{3} \mathrm{CN}$, $0.6 \% \mathrm{HCOOH}$ was added for MS analysis.

\subsection{Identification of Lipid Droplet Proteins by Liquid Chromatography-Tandem Mass Spectrometry}

Separation and sequencing of tryptic peptides with liquid chromatography-tandem mass spectrometry (LC-MS/MS) was performed using a Q-Tof Premier (Jasco International) coupled with nanoACQUITY UPLC® (Waters). Peptide fragments were applied onto a nanoACQUITY BEH C18 $100 \mu \mathrm{m} \times 100 \mathrm{~mm}$ column, and eluted at a flow rate of 0.4 $\mu \mathrm{l} / \mathrm{min}$ for 30 min using a $3-40 \%$ linear gradient of solvent $\mathrm{B}$ of $0.1 \% \mathrm{HCOOH}$ in $\mathrm{CH}_{3} \mathrm{CN}$ and $60-97 \%$ linear gradient of solvent $\mathrm{A}$ of $0.1 \% \mathrm{HCOOH}$ in water. Analysis was performed using a positive ion mode at $3 \mathrm{kV}$ capillary voltage. The mass range was set from 350 to $1700 \mathrm{~m} / \mathrm{z}$, and the MS/MS spectra were acquired for the peaks with at least 15 counts. The spectra were processed using ProteinLynx v4.1 software (Waters) and MASCOT (www.matrixscience. com) database searches of the NCBInr database for all Viridiplantae sequences. Peptides that could not be identified in the database were identified as partial sequences by de novo sequences using PepSeq (Waters). In this case, homologous proteins were predicted using BPASTP (DDBJ, http://www. ddbj.nig.ac.jp/welcome-j.html). Proteins were identified by the assignment of at least three peptide fragments, but proteins of less than $21 \mathrm{kDa}$ were assigned using at least two peptide fragments. Proteins were predicted with homology of more than $70 \%$ using at least three peptides.

\subsection{Preparation of Antibodies Against Oleosin}

Sample II was recovered as described in "Isolation and purification of lipid droplets" of Sect. 2.2. A five-fold volume of acetone was added to sample II. The sample was left at $-30{ }^{\circ} \mathrm{C}$ overnight and was centrifuged at $9000 \times g$ for $30 \mathrm{~min}$. The supernatant was removed, and the precipitate was collected, and dried under reduced pressure. The dried samples were dissolved in $2 \times$ SDS sample buffer for SDS-PAGE. The samples were applied for SDS-PAGE. Bands corresponding to oleosin of $15-\mathrm{kDa} \sim 17-\mathrm{kDa}$ were cut out, and the gel slices were pressed through a plastic syringe and stirred in $50 \mathrm{mM}$ Tris- $\mathrm{HCl}$ buffer $(\mathrm{pH} 8.1)$ containing $0.1 \%$ SDS, 5\% 2-mercaptoethanol, $1 \mathrm{mM}$ EDTA overnight at room temperature. The sample was centrifuged at $9000 \times g$ for $20 \mathrm{~min}$. The supernatant was recovered, and a five-fold volume of acetone was added to the supernatant. The sample was left at $-30{ }^{\circ} \mathrm{C}$ overnight and centrifuged at $9000 \times g$ for $30 \mathrm{~min}$. The supernatant was removed, and the precipitate was collected and dried under reduced pressure. The dried sample was dissolved in $10 \mathrm{mM}$ phosphate buffer containing $0.15 \mathrm{M} \mathrm{NaCl}, \mathrm{pH} 7.1$ (PBS) and used as purified oleosin for immunization. Purified oleosin $(5 \mu \mathrm{g})$ was suspended in $250 \mu \mathrm{l}$ PBS, mixed 
with the same amount of Freund's complete adjuvant for the first injection or Freund's incomplete adjuvant (Difco $\mathrm{Lab}$ ) for subsequent injections. These mixtures were used as antigens for the preparation of polyclonal antibodies. SPF BALB/c mice were immunized by injecting antigens subcutaneously and intraperitoneally. Four injections at intervals of 10 days were given, and the mice were bled after the last injection. These experiments were approved by the Institutional Animal Care and Use Committee of Kinki University. Control serum was withdrawn from mice before the first injection.

\subsection{Preparation of Frozen Sections or Native Lipid Droplet and Immune-Confocal Microscopy}

Sesame seeds were fixed in $4 \%$ formaldehyde for $8 \mathrm{~h}$ at 4 ${ }^{\circ} \mathrm{C}$. After removal of formaldehyde, $10 \%$ sucrose solution was added. Samples were incubated for $4 \mathrm{~h}$ at $4{ }^{\circ} \mathrm{C}$. The sucrose concentration was changed from 10 to $15 \%$, and samples were incubated for $4 \mathrm{~h}$ at $4{ }^{\circ} \mathrm{C}$. Afterward, the sucrose concentration was changed from 15 to $20 \%$, and samples were incubated for $8 \mathrm{~h}$ at $4{ }^{\circ} \mathrm{C}$. Samples were embedded in the OCT compound (Sakura Finetek) and cut into $2 \mu \mathrm{m}$ thick frozen section using a Leica CM1850. Sections were incubated in $2 \%$ bovine serum albumen (BSA)/PBS, for 45 min at RT. Polyclonal mouse anti-sesame oleosin antibodies were diluted 100-fold with PBS and applied onto the sections for $2 \mathrm{~h}$ at RT. Sections were washed twice with PBS at intervals of $5 \mathrm{~min}$. Fluorescein isothiocyanate (FITC)-conjugated goat anti-mouse IgG as the secondary antibody was diluted 100-fold with PBS and applied onto the sections for $2 \mathrm{~h}$ at RT. The sections were washed twice with PBS at intervals of $5 \mathrm{~min}$. Next, a polyclonal anti-soybean $11 \mathrm{~S}$ globulin antibody was diluted 100-fold with PBS and applied onto sections for $2 \mathrm{~h}$ at RT. The sections were washed twice with PBS at intervals of 5 min. Rhodamine-conjugated goat anti-rabbit IgG was diluted 100-fold with PBS and applied onto sections for $2 \mathrm{~h}$ at RT. The sections were washed twice with PBS at intervals of $5 \mathrm{~min}$. All sections were observed using a confocal microscope (BioRad Radiance 2000).

Native lipid droplets as described in the "Isolation and purification of lipid droplets" in the Materials and Methods were prepared, and they were treated for $2 \mathrm{~h}$ at RT with four kinds of detergents, Triton X-100, Tween 20, SDS or CTAB, at $0.5 \%$ final concentrations. After washing with PBS, the samples were incubated with a polyclonal anti-soybean 11S globulin antibody for $2 \mathrm{~h}$ on ice, and washed with PBS. The samples were incubated with FITC-conjugated goat anti-rabbit IgG for $2 \mathrm{~h}$ on ice. After washing with PBS, the samples were observed with a BioRad confocal microscope (Radiance 2100).

\section{Results}

\subsection{Isolation and Purification of Lipid Droplets}

In this study, we attempted to isolate as many proteins from lipid droplets as possible, including proteins that weakly adhere to the outer monolayer surface of lipid droplets via ionic bonds. As a first step, the homogenizing conditions of sesame seeds were studied. After immersing in $0.6 \mathrm{M}$ sucrose, $10 \mathrm{mM} \mathrm{Na} 2 \mathrm{HPO}_{4}-\mathrm{KH}_{2} \mathrm{PO}_{4}$, $\mathrm{pH} 7.5$ (homogenizing buffer), sesame seeds were homogenized with a polytron homogenizer PT2100 at constant speed from 15,000 to $22,000 \mathrm{rpm}$ for $20 \mathrm{~s}$. At less than 19,000 rpm, the yield of lipid droplet proteins was only one-tenth of that at higher speeds. There was no difference in the recovery amount of lipid droplet proteins from 20,000 to 22,000 rpm with the polytron homogenizer. Addition of $0.2 \mathrm{M} \mathrm{KCl}, 2 \mathrm{mM}$ $\mathrm{MgCl}_{2}$, or $2 \mathrm{mM} \mathrm{CaCl}_{2}$ into the homogenizing buffer did not produce any effects on the yield of lipid droplets. However, the appearance of a few spots by two-dimensional electrophoresis became stronger with these salt additions, whereas that of a few spots became weaker (data not shown). Moreover, sesame lipid droplets were prepared in mild conditions without treatment with high salt concentrations or detergents [10] to isolate as many proteins from lipid droplets as possible. Sesame lipid droplets were purified through each step by sucrose gradient centrifugation after the isolation of lipid droplets (Fig. 2). The strengths of protein bands of oleosin, caleosin, and steroleosin, which have been reported as

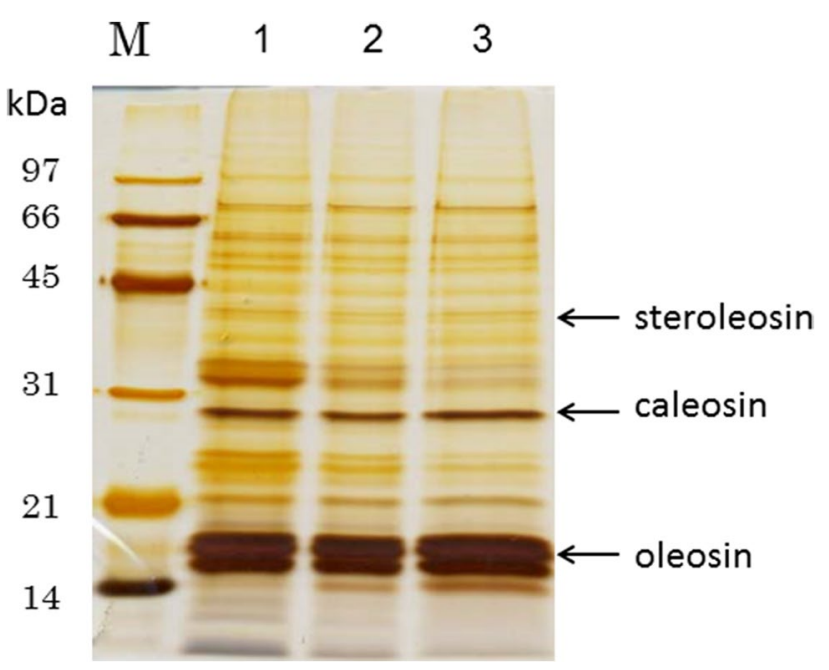

Fig. 2 SDS-PAGE of lipid droplet samples from each step of the sucrose gradient centrifugation. Lane $M$ shows the positions of molecular mass markers in kilodaltons $(\mathrm{kDa})$. Lane 1 , sample I; lane 2, sample II; lane 3, sample III, as described in the Materials and Methods. Arrows show the positions of oleosin, caleosin, and steroleosin 
major components of lipid droplets [11], were not subjected to changes through each step.

\subsection{Identification of Lipid Droplet Proteins by LC-MS/MS}

Lipid droplet sample III was prepared for lipid droplet proteomics, and subjected to two-dimensional electrophoresis. As a result, 139 spots appeared on the two-dimensional electrophoresis gel as lipid droplet components (Fig. 3). Of 139 spots, 103 spots were identified by the assignment of at least three peptide fragments. The 103 proteins in lipid droplets were a remarkably high proportion of lipid droplet components, compared with the three major proteins of lipid droplets, oleosin, caleosin, and steroleosin, as reported previously [11]. In other plant lipid droplets, more than 20 proteins were identified in Zea mays [12] and more than 200 proteins in Chlamydomonas reinhardtii [13]. The number of proteins associated with lipid droplets increases with time $[14,15]$. It has been suggested that OBAP1, a member of a discovered family of lipid droplet-associated proteins (OBAP) is involved in the regulation of lipid droplet size [16].

Results with LC-MS/MS showed that 103 spots were identified as lipid droplet proteins (Table 1), among them protein disulfide isomerase, calreticulin, $\mathrm{BiP}$, and elongation factor were marker proteins of the endoplasmic reticulum (ER), and 11S globulin, 7S globulin, 2S albumin were marker proteins of protein bodies. Mitochondrial ATP synthase, mitochondrial processing peptidase, and 34-kDa outer mitochondrial membrane protein porin-like protein are mitochondrial origin proteins.

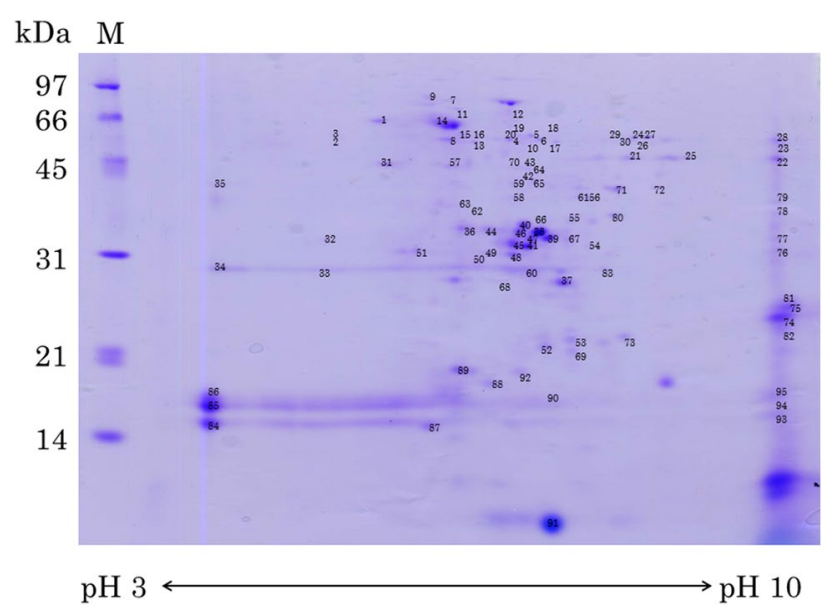

Fig. 3 Two-dimensional electrophoresis of lipid droplet proteins in sample III from sesame seeds. Protein spots were identified using a Q-Tof Premier. The number of each spot corresponds to that in Table 1

\subsection{Localization of 115 Globulin in Lipid Droplets}

The localization of $11 \mathrm{~S}$ globulin in lipid droplets was shown using frozen sections and immunoconfocal microscopy (Fig. 4). When lipid droplets were confirmed by using antibody against oleosin, the fluorescence from $11 \mathrm{~S}$ globulin was observed in the lipid droplets. Moreover, isolated native lipid droplets were treated with four kinds of detergents, as described in the Materials and Methods. Only the lipid droplets treated with CTAB emitted fluorescence, when anti-soybean $11 \mathrm{~S}$ globulin antibody as the primary antibody and FITC-conjugated goat anti rabbit IgG as the secondary antibody were applied (Fig. 5). The lipid droplets treated with other detergents, Triton X-100, Tween 20, or SDS, did not emit any fluorescence. The difference in results between CTAB and the three other detergents might be due to the curious properties of lipid droplet membranes.

\subsection{Modification of Lipid Droplet Proteins}

Lipid droplets are surrounded by the monolayer, which might have negative electric charges on the surface, from the ER membrane. This suggested the existence of phosphate groups on the surface of lipid droplets (cf. Fig. 6). Modification of several proteins, including oleosin, was observed (cf. Fig. 3). Modification of oleosin was investigated by phosphatase treatment. Acid phosphatase treatment was much more effective in shifting from acidic to basic sites (Fig. 6). The results clearly indicated that oleosin proteins are phosphorylated. It was conjectured that phosphate groups might prevent the fusion of lipid droplets, although it had been believed that oleosin proteins play an important role in inhibiting lipid droplets from adhering to each other ([10], trypsin treatment exp).

\section{Discussion}

Although 103 spots were identified as lipid droplet proteins (Table 1), protein disulfide isomerase, calreticulin, $\mathrm{BiP}$, and elongation factor were used as marker proteins of the ER, and $11 \mathrm{~S}$ globulin, $7 \mathrm{~S}$ globulin, $2 \mathrm{~S}$ albumin were used as marker proteins for protein bodies. Mitochondrial ATP synthase, mitochondrial processing peptidase, and 34-kDa outer mitochondrial membrane protein porin-like protein are marker proteins for mitochondria. These results suggested that interactions between lipid droplets and other organelles, including the ER, protein bodies, and mitochondria, might occur through attachment between membranes [17]. The results were not due to organelle degradation, as indicated by the fact that each protein from the other organelles, other than the protein body, was derived from the organelle membrane. However, 
Table 1 Protein assignments of lipid droplet proteins by Q-T of analysis

\begin{tabular}{|c|c|c|c|c|c|c|c|c|}
\hline Spot no. & Acc. no. & Protein name & Species & $\mathrm{MW}(\mathrm{kDa}) /$ & $\mathrm{pI}(\mathrm{T})$ & $\begin{array}{l}\text { MW } \\
(\mathrm{kDa}) /\end{array}$ & $\mathrm{pI}(\mathrm{E})$ & Match \\
\hline \multicolumn{9}{|c|}{ Known oil body proteins } \\
\hline No33 & gi:6478218[NCBI] & Caleosin & S. indicum & $27.78 /$ & 5.59 & $29 /$ & 4.5 & 7 \\
\hline No34 & gi:6478218[NCBI] & Caleosin & S. indicum & $27.78 /$ & 5.59 & $29 /$ & 3 & 6 \\
\hline No35 & gi:21311775[NCBI] & Steroleosin-B & S. indicum & $41.28 /$ & 6.99 & $41 /$ & 3 & 6 \\
\hline No63 & gi:15824408[NCBI] & Steroleosin & S. indicum & $39.71 /$ & 5.71 & $39 /$ & 6 & 7 \\
\hline No84 & Q2TM28[EMBL] & Oleosin & C. canephora & $15.17 /$ & 8.11 & $15 /$ & 3 & 3 \\
\hline No85 & gi:10834827[NCBI] & Oleosin & S. indicum & $17.41 /$ & 9.84 & $17 /$ & 3 & 4 \\
\hline No86 & Q9XHP2[EMBL] & $15 \mathrm{kD}$ oleosin & S. indicum & $15.18 /$ & 10.08 & $17 /$ & 3 & 2 \\
\hline No93 & Q2TM28[EMBL] & Oleosin & C. canephora & $15.17 /$ & 8.11 & $15 /$ & 10 & 3 \\
\hline No94 & gi:10834827[NCBI] & Oleosin & S. indicum & $17.41 /$ & 9.84 & $17 /$ & 10 & 3 \\
\hline No95 & Q9XHP2[EMBL] & $15 \mathrm{kD}$ oleosin & S. indicum & $15.18 /$ & 10.08 & $17 /$ & 10 & 4 \\
\hline \multicolumn{9}{|c|}{ Seed storage proteins } \\
\hline No21 & gi:13183177[NCBI] & 7S globulin (homologue) & S. indicum & $67.88 /$ & 7.55 & $47 /$ & 8 & 6 \\
\hline No22 & gi:13183177[NCBI] & $7 \mathrm{~S}$ globulin & S. indicum & $67.88 /$ & 7.55 & $47 /$ & 10 & 8 \\
\hline No25 & gi:13183177[NCBI] & 7S globulin (homologue) & S. indicum & $67.88 /$ & 7.55 & $47 /$ & 8.8 & 4 \\
\hline No26 & gi:75315270[NCBI] & $\begin{array}{l}11 \mathrm{~S} \text { globulin seed storage protein } 2 \\
\text { precursor }\end{array}$ & S. indicum & $52.08 /$ & 7.72 & $52 /$ & 8.2 & 11 \\
\hline No27 & gi:13183177[NCBI] & $7 \mathrm{~S}$ globulin & S. indicum & $67.88 /$ & 7.55 & $57 /$ & 8.2 & 7 \\
\hline No28 & gi:13183177[NCBI] & $7 \mathrm{~S}$ globulin & S. indicum & $67.88 /$ & 7.55 & $56 /$ & 10 & 4 \\
\hline No30 & gi:75315270[NCBI] & $\begin{array}{l}11 \mathrm{~S} \text { globulin seed storage protein } 2 \\
\text { precursor }\end{array}$ & S. indicum & $52.08 /$ & 7.72 & $52 /$ & 7.9 & 14 \\
\hline No38 & gi:81238592[NCBI] & $\begin{array}{l}\text { 11S globulin precursor isoform } 3 \text { (A } \\
\text { subunit) }\end{array}$ & S. indicum & $55.59 /$ & 8.23 & $33 /$ & 7 & 11 \\
\hline No39 & gi:81238594[NCBI] & $\begin{array}{l}\text { 11S globulin precursor isoform } 4 \text { (A } \\
\text { subunit) }\end{array}$ & S. indicum & $52.99 /$ & 8.2 & $33 /$ & 7.2 & 17 \\
\hline No41 & gi:75315270[NCBI] & $\begin{array}{l}\text { 11S globulin seed storage protein } 2 \text { pre- } \\
\text { cursor (A subunit) }\end{array}$ & S. indicum & $52.08 /$ & 7.72 & $32 /$ & 6.9 & 15 \\
\hline No44 & gi: $13183173[\mathrm{NCBI}]$ & $11 \mathrm{~S}$ globulin (A subunit) & S. indicum & $56.78 /$ & 8.57 & $34 /$ & 6.4 & 8 \\
\hline No45 & gi:75315270[NCBI] & $\begin{array}{l}\text { 11S globulin seed storage protein } 2 \text { pre- } \\
\text { cursor (A subunit) }\end{array}$ & S. indicum & $52.08 /$ & 7.72 & $32 /$ & 6.7 & 13 \\
\hline No46 & gi:81238592[NCBI] & $\begin{array}{l}\text { 11S globulin precursor isoform } 3 \text { (A } \\
\text { subunit) }\end{array}$ & S. indicum & $55.59 /$ & 8.23 & $33 /$ & 6.8 & 10 \\
\hline No47 & gi:81238594[NCBI] & $\begin{array}{l}\text { 11S globulin precursor isoform } 4 \text { (A } \\
\text { subunit) }\end{array}$ & S. indicum & $52.99 /$ & 8.2 & $33 /$ & 6.9 & 8 \\
\hline No52 & gi:81238594[NCBI] & 11S globulin precursor isoform 4 & S. indicum & $52.99 /$ & 8.2 & $22 /$ & 7.1 & 5 \\
\hline No53 & gi:81238594[NCBI] & 11S globulin precursor isoform 4 & S. indicum & $52.99 /$ & 8.2 & $23 /$ & 7.4 & 4 \\
\hline No54 & gi:81238594[NCBI] & $\begin{array}{l}\text { 11S globulin precursor isoform } 4 \text { (A } \\
\text { subunit) }\end{array}$ & S. indicum & $52.99 /$ & 8.2 & $33 /$ & 7.6 & 7 \\
\hline No55 & gi:13183177[NCBI] & $7 \mathrm{~S}$ globulin & S. indicum & $67.88 /$ & 7.55 & $35 /$ & 7.4 & 3 \\
\hline No60 & gi:75315270[NCBI] & $\begin{array}{l}\text { 11S globulin seed storage protein } 2 \text { pre- } \\
\text { cursor (A subunit) }\end{array}$ & S. indicum & $52.08 /$ & 7.72 & 29/ & 6.8 & 6 \\
\hline No66 & gi:81238594[NCBI] & $\begin{array}{l}\text { 11S globulin precursor isoform } 4 \text { (A } \\
\text { subunit) (homologue) }\end{array}$ & S. indicum & $52.99 /$ & 8.2 & $36 /$ & 7.1 & 6 \\
\hline No67 & gi:81238594[NCBI] & $\begin{array}{l}\text { 11S globulin precursor isoform } 4 \text { (A } \\
\text { subunit) }\end{array}$ & S. indicum & $52.99 /$ & 8.2 & $33 /$ & 7.4 & 7 \\
\hline No68 & gi:81238594[NCBI] & $11 \mathrm{~S}$ globulin precursor isoform 4 & S. indicum & $52.99 /$ & 8.2 & $27 /$ & 6.5 & 6 \\
\hline No69 & gi:81238594[NCBI] & $\begin{array}{l}\text { 11S globulin precursor isoform } 4 \text { (A } \\
\text { subunit) }\end{array}$ & S. indicum & $52.99 /$ & 8.2 & $21 /$ & 7.4 & 6 \\
\hline No74 & gi:81238592[NCBI] & $\begin{array}{l}\text { 11S globulin precursor isoform } 3 \text { (B } \\
\text { subunit) }\end{array}$ & S. indicum & $55.59 /$ & 8.23 & $24 /$ & 10 & 7 \\
\hline No74 & gi:81238594[NCBI] & $\begin{array}{l}\text { 11S globulin precursor isoform } 4 \text { (B } \\
\text { subunit) }\end{array}$ & S. indicum & $52.99 /$ & 8.2 & $24 /$ & 10 & 6 \\
\hline
\end{tabular}


Table 1 (continued)

\begin{tabular}{|c|c|c|c|c|c|c|c|c|}
\hline Spot no. & Acc. no. & Protein name & Species & MW (kDa)/ & $\mathrm{pI}(\mathrm{T})$ & $\begin{array}{l}\mathrm{MW} \\
(\mathrm{kDa}) /\end{array}$ & $\mathrm{pI}(\mathrm{E})$ & Match \\
\hline No75 & gi:81238594[NCBI] & $\begin{array}{l}\text { 11S globulin precursor isoform } 4 \text { (B } \\
\text { subunit) }\end{array}$ & S. indicum & $52.99 /$ & 8.2 & $25 /$ & 10 & 4 \\
\hline No75 & gi:75315270[NCBI] & $\begin{array}{l}\text { 11S globulin seed storage protein } 2 \text { pre- } \\
\text { cursor (B subunit) }\end{array}$ & S. indicum & $52.08 /$ & 7.72 & $25 /$ & 10 & 7 \\
\hline No76 & gi:75315270[NCBI] & $\begin{array}{l}\text { 11S globulin seed storage protein } 2 \text { pre- } \\
\text { cursor (A subunit) }\end{array}$ & S. indicum & $51.79 /$ & 7.72 & $35 /$ & 10 & 12 \\
\hline No77 & gi:81238592[NCBI] & $\begin{array}{l}11 \mathrm{~S} \text { globulin precursor isoform } 3 \text { (A } \\
\text { subunit) }\end{array}$ & S. indicum & $55.59 /$ & 8.23 & $33 /$ & 10 & 12 \\
\hline No77 & gi:81238594[NCBI] & $\begin{array}{l}\text { 11S globulin precursor isoform } 4 \text { (A } \\
\text { subunit) }\end{array}$ & S. indicum & $52.99 /$ & 8.2 & $33 /$ & 10 & 8 \\
\hline No77 & gi:13183173[NCBI] & $11 \mathrm{~S}$ globulin (A subunit) & S. indicum & $56.78 /$ & 8.57 & $33 /$ & 10 & 6 \\
\hline No81 & gi:75315270[NCBI] & $\begin{array}{l}\text { 11S globulin seed storage protein } 2 \text { pre- } \\
\text { cursor (B subunit) }\end{array}$ & S. indicum & $52.08 /$ & 7.72 & $26 /$ & 10 & 10 \\
\hline No82 & gi:13183173[NCBI] & 11S globulin (B subunit) & S. indicum & $56.78 /$ & 8.57 & $24 /$ & 10 & 10 \\
\hline No90 & gi:81238592[NCBI] & $11 \mathrm{~S}$ globulin precursor isoform 3 & S. indicum & $55.59 /$ & 8.23 & $17 /$ & 7.5 & 3 \\
\hline No91 & gi:75267546[NCBI] & $\begin{array}{l}2 \mathrm{~S} \text { seed storage protein } 1 \\
\text { precursor(large subunit) }\end{array}$ & S. indicum & $18.08 /$ & 6.1 & 9/ & 7.2 & 3 \\
\hline \multicolumn{9}{|c|}{ Membrane traffic proteins } \\
\hline No1 & Q9SRG3[Swiss-Prot] & Protein disulfide-isomerase 2 precursor & A. thaliana & $56.36 /$ & 4.9 & $62 /$ & 5.2 & 3 \\
\hline No2 & gi:117165712[NCBI] & Calreticulin-1 & G. $\max$ & $48.31 /$ & 4.43 & $58 /$ & 4.7 & 5 \\
\hline No7 & gi:562006[NCBI] & PsHSP71.2 & P. sativum & $71.52 /$ & 5.17 & $80 /$ & 5.9 & 8 \\
\hline No9 & Q587K1[EMBL] & $\mathrm{BiP}$ & G. $\max$ & $73.59 /$ & 5.06 & $82 /$ & 5.7 & 4 \\
\hline No10 & gi:14334534[NCBI] & $\begin{array}{l}\text { Putative mitochondrial processing } \\
\text { peptidase alpha subunit }\end{array}$ & A. thaliana & $54.21 /$ & 6.16 & $49 /$ & 6.8 & 3 \\
\hline No11 & gi:399940[NCBI] & $\begin{array}{l}\text { Heat shock } 70 \mathrm{kDa} \text { protein, mitochon- } \\
\text { drial precursor }\end{array}$ & P. vulgaris & $72.72 /$ & 5.95 & $75 /$ & 6 & 8 \\
\hline No14 & gi:16221[NCBI] & Chaperonin hsp60 & A. thaliana & $61.65 /$ & 5.66 & $60 /$ & 5.8 & 14 \\
\hline No15 & gi:2501850[NCBI] & GDP dissociation inhibitor & N. tabacum & $50.12 /$ & 5.44 & $57 /$ & 6.1 & 3 \\
\hline No16 & gi:13959067[NCBI] & Mitochondrial processing peptidase & A. marina & $59.37 /$ & 5.93 & $57 /$ & 6.2 & 4 \\
\hline No31 & Q9S9N1[EMBL] & Heat shock protein hsp70 & A. thaliana & $70.91 /$ & 5.3 & $45 /$ & 5.2 & 3 \\
\hline No78 & Q2PYX4[EMBL] & $\begin{array}{l}34 \mathrm{kD} \text { outer mitochondrial membrane } \\
\text { protein porin-like }\end{array}$ & S. tuberosum & $29.42 /$ & 6.5 & $37 /$ & 10 & 4 \\
\hline No88 & Q01545[Swiss-Prot] & $18.8 \mathrm{kDa}$ class II heat shock protein & I. nil & $18.77 /$ & 5.21 & $17 /$ & 6.4 & 3 \\
\hline No89 & Q9SWE4[EMBL] & $\begin{array}{l}\text { Low molecular weight heat-shock } \\
\text { protein }\end{array}$ & N. tabacum & $17.17 /$ & 5.59 & $19 /$ & 6 & 3 \\
\hline \multicolumn{9}{|c|}{ Cellular respiration proteins } \\
\hline No4 & gi:19281[NCBI] & Enolase & L. esculentum & $47.76 /$ & 5.68 & $54 /$ & 6.7 & 5 \\
\hline No6 & gi:19281[NCBI] & Enolase & L. esculentum & $47.76 /$ & 5.68 & $53 /$ & 7 & 3 \\
\hline No42 & gi:121485004[NCBI] & Cytosolic phosphoglycerate kinase & H. annuиs & $42.33 /$ & 5.82 & $42 /$ & 7 & 3 \\
\hline No43 & gi:7159004[NCBI] & Alcohol dehydrogenase 2 & P. sinjiangenesis & $22.62 /$ & 5.28 & $44 /$ & 7 & 3 \\
\hline No56 & gi:120676[NCBI] & $\begin{array}{l}\text { Glyceraldehyde-3-phosphate dehydro- } \\
\text { genase, cytosolic }\end{array}$ & N. tabacum & $35.68 /$ & 6.14 & $39 /$ & 7.6 & 3 \\
\hline No58 & gi:18202485[NCBI] & Malate dehydrogenase cytoplasmic & Z. mays & $35.90 /$ & 5.77 & $40 /$ & 6.8 & 5 \\
\hline No59 & Q655T1[EMBL] & Cytosolic phosphoglycerate kinase 1 & O. sativa & $42.27 /$ & 6.19 & $42 /$ & 6.8 & 4 \\
\hline No65 & Q9FR11[EMBL] & Pyruvate dehydrogenase & S. lycopersicum & $43.37 /$ & 8.06 & $41 /$ & 7.2 & 3 \\
\hline No71 & gi:218157[NCBI] & Cytoplasmic aldolase & O. sativa & $38.71 /$ & 6.56 & $40 /$ & 7.9 & 3 \\
\hline No72 & Q43359[EMBL] & $\begin{array}{l}\text { cytosolic glyceraldehyde-3-phosphate } \\
\text { dehydrogenase GAPC4 }\end{array}$ & Z. mays & $36.45 /$ & 6.61 & $40 /$ & 8.4 & 4 \\
\hline \multicolumn{9}{|c|}{ Redox proteins } \\
\hline No12 & gi: $15240075[\mathrm{NCBI}]$ & Succinate dehydrogenase $1-1$ & A. thaliana & $70.24 /$ & 5.86 & $67 /$ & 6.7 & 7 \\
\hline No18 & gi:3309269[NCBI] & $\begin{array}{l}\text { Ferric leghemoglobin reductase- } 2 \\
\text { precursor }\end{array}$ & G. $\max$ & $53.31 /$ & 6.9 & $58 /$ & 7.2 & 3 \\
\hline
\end{tabular}


Table 1 (continued)

\begin{tabular}{|c|c|c|c|c|c|c|c|c|}
\hline Spot no. & Acc. no. & Protein name & Species & MW (kDa)/ & $\mathrm{pI}(\mathrm{T})$ & $\begin{array}{l}\text { MW } \\
(\mathrm{kDa}) /\end{array}$ & $\mathrm{pI}(\mathrm{E})$ & Match \\
\hline $\mathrm{No} 24$ & Q48561[Swiss-Prot] & Catalase-4 & G. $\max$ & $56.73 /$ & 6.8 & $56 /$ & 8.1 & 3 \\
\hline No29 & gi:90818818[NCBI] & Catalase & P. deltoides & $57.19 /$ & 7.09 & $56 /$ & 7.8 & 10 \\
\hline No36 & Q9FZ42[Swiss-Prot] & $\begin{array}{l}\text { Glucose and ribitol dehydrogenase } \\
\text { homologue } 1\end{array}$ & A. thaliana & $31.38 /$ & 6.11 & $34 /$ & 6.1 & 3 \\
\hline No37 & gi:19423862[NCBI] & 1 cys peroxiredoxin & $X$. viscosa & $24.48 /$ & 6.31 & $27 /$ & 7.3 & 4 \\
\hline No61 & gi:151301848[NCBI] & Putative aldo/keto reductase 2 & S. miltiorrhiza & $37.85 /$ & 6.09 & $40 /$ & 7.5 & 6 \\
\hline No65 & Q6V4H0[EMBL] & 10-hydroxygeraniol oxidoreductase & C. roseus & $38.93 /$ & 6.67 & $41 /$ & 7.2 & 3 \\
\hline No70 & gi:45935133[NCBI] & Putative dihydroflavonol reductase & I. trifida & $46.11 /$ & 5.78 & $44 /$ & 6.8 & 4 \\
\hline \multicolumn{9}{|c|}{ Energy production proteins } \\
\hline No5 & gi:12986[NCBI] & F1 ATPase adenosinetriphosphatase & H. annuus & $55.45 /$ & 6.02 & $55 /$ & 6.9 & 6 \\
\hline No17 & gi:114408[NCBI] & $\begin{array}{l}\text { ATP synthase subunit alpha, mitochon- } \\
\text { drial }\end{array}$ & O. biennis & $55.84 /$ & 6.23 & $47 /$ & 7.2 & 3 \\
\hline No19 & gi:5305369[NCBI] & ATP synthase alpha chain & V. radiata & $55.55 /$ & 6.23 & $58 /$ & 6.7 & 4 \\
\hline No20 & gi:903732[NCBI] & F1ATPase alpha subunit & H. annuиs & $55.76 /$ & 6.23 & $57 /$ & 6.6 & 10 \\
\hline \multicolumn{9}{|c|}{ Seed maturation proteins } \\
\hline No32 & Q9SEL0[EMBL] & Seed maturation protein PM24 & G. $\max$ & $26.84 /$ & 5.14 & $34 /$ & 4.6 & 4 \\
\hline No51 & Q9SEL0[EMBL] & Seed maturation protein PM24 & G. $\max$ & $26.84 /$ & 5.14 & $32 /$ & 5.6 & 4 \\
\hline No87 & gi: $1141784[\mathrm{NCBI}]$ & Em protein & V. radiata & $10.93 /$ & 6.62 & $15 /$ & 5.7 & 4 \\
\hline No92 & A6N8C4[EMBL] & Pathogen-related protein STH-2 & S. miltiorrhiza & $17.97 /$ & 5.4 & $19 /$ & 6.8 & 4 \\
\hline \multicolumn{9}{|c|}{ Protein synthesis related proteins } \\
\hline No23 & gi:24371057[NCBI] & Eukaryotic elongation factor $1 \mathrm{~A}$ & S. japonica & $49.74 /$ & 9.2 & $52 /$ & 10 & 4 \\
\hline No33 & gi:124484511[NCBI] & $\begin{array}{l}\text { Alpha chain of nascent polypeptide } \\
\text { associated complex }\end{array}$ & N. thamiana & 21.91/ & 4.32 & $29 /$ & 4.5 & 3 \\
\hline No62 & gi:38350579[NCBI] & Cystein synthase & N. plumbaginifolia & $34.12 /$ & 5.71 & $37 /$ & 6.2 & 4 \\
\hline No64 & gi:11181616[NCBI] & Translational elongation factor EF-TuM & Z. mays & $48.74 /$ & 5.99 & $43 /$ & 7.2 & 5 \\
\hline \multicolumn{9}{|c|}{ Other proteins } \\
\hline No3 & gi:1161252[NCBI] & Nucleosome assembly protein 1 & G. $\max$ & $41.07 /$ & 4.32 & $59 /$ & 4.7 & 3 \\
\hline No13 & gi:37953301[NCBI] & Alanine aminotransferase & C. annuиs & $53.33 /$ & 5.29 & $50 /$ & 6.2 & 3 \\
\hline No37 & gi:13183179[NCBI] & Cystatin & S. indicum & $22.33 /$ & 6.17 & $27 /$ & 7.3 & 6 \\
\hline No40 & Q8GSE7[EMBL] & TAG factor protein & L. angustifolius & $32.21 /$ & 6.33 & $36 /$ & 6.8 & 5 \\
\hline No48 & Q8GXX2[EMBL] & Putative uncharacterized protein & A. thaliana & $26.70 /$ & 5.79 & $32 /$ & 6.7 & 3 \\
\hline No49 & Q1PE68[EMBL] & hypothetical protein & A. thaliana & $27.74 /$ & 7.64 & $32 /$ & 6.4 & 3 \\
\hline No50 & Q49407[EMBL] & $\begin{array}{l}\text { Putative uncharacterized protein } \\
\text { AT4g18920 }\end{array}$ & A. thaliana & $28.67 /$ & 7.65 & $32 /$ & 6.3 & 3 \\
\hline No57 & gi:122891673[NCBI] & Actin & S. dulcis & $27.37 /$ & 5.21 & $44 /$ & 5.9 & 7 \\
\hline No70 & gi:147774828[NCBI] & Hypothetical protein & $V$. vinifera & $38.16 /$ & 6.32 & $44 /$ & 6.8 & 5 \\
\hline No73 & Q8L9C2[EMBL] & Ethylene-responsive protein & A. thaliana & $21.38 /$ & 5.53 & $23 /$ & 8 & 4 \\
\hline
\end{tabular}

Spot no. corresponds to that in Fig. 3. Acc. no: accession number from NCBI, EMBL or Swiss-Prot database; MW(kDa)/pI(T): molecular weight $(\mathrm{kDa}) /$ isoelectric point of theoretical values from database; $\mathrm{MW}(\mathrm{kDa}) / \mathrm{pI}(\mathrm{E})$ : molecular weight $(\mathrm{kDa}) /$ isoelectric point of experimental values; Match, number of matched peptides

enolase, alcohol dehydrogenase, malate dehydrogenase, aldolase, phosphoglycerate kinase, and glyceraldehyde3-phosphate dehydrogenase are cytosolic proteins, and they might be contaminants at the process of lipid droplet isolation. Indeed, Katavic et al. [18] described that hydrophobic internal protein body membranes might adhere to lipid droplets, which makes it very difficult to isolate lipid droplets without contamination of storage proteins even after stringent washing with salt and urea. Some papers suggested about the possibilities of contamination from the other organelles during the isolation of lipid droplets [19-21]. Alternatively, they might be correlated with the formation of lipid droplets, as shown in Figs. 4 and 5, indicating that lipid droplets indeed consist of $11 \mathrm{~S}$ globulins. The existence of 103 spots in lipid droplets suggested that sesame lipid droplets do not only function in the storage of 
Fig. 4 Localization of $11 \mathrm{~S}$ globulins in lipid droplets of frozen sections. Frozen sections were incubated with polyclonal mouse anti-oleosin or polyclonal rabbit anti-soybean $11 \mathrm{~S}$ After the anti-oleosin primary antibody, the sections were incubated with FITC-conjugated goat anti-mouse IgG secondary antibodies. Next, after the anti-soybean $11 \mathrm{~S}$ globulin primary antibody, the sections were incubated with rhodamineconjugated goat anti-rabbit IgG secondary antibody. Scale bars show $1 \mu \mathrm{m}$ globulin primary antibodies.
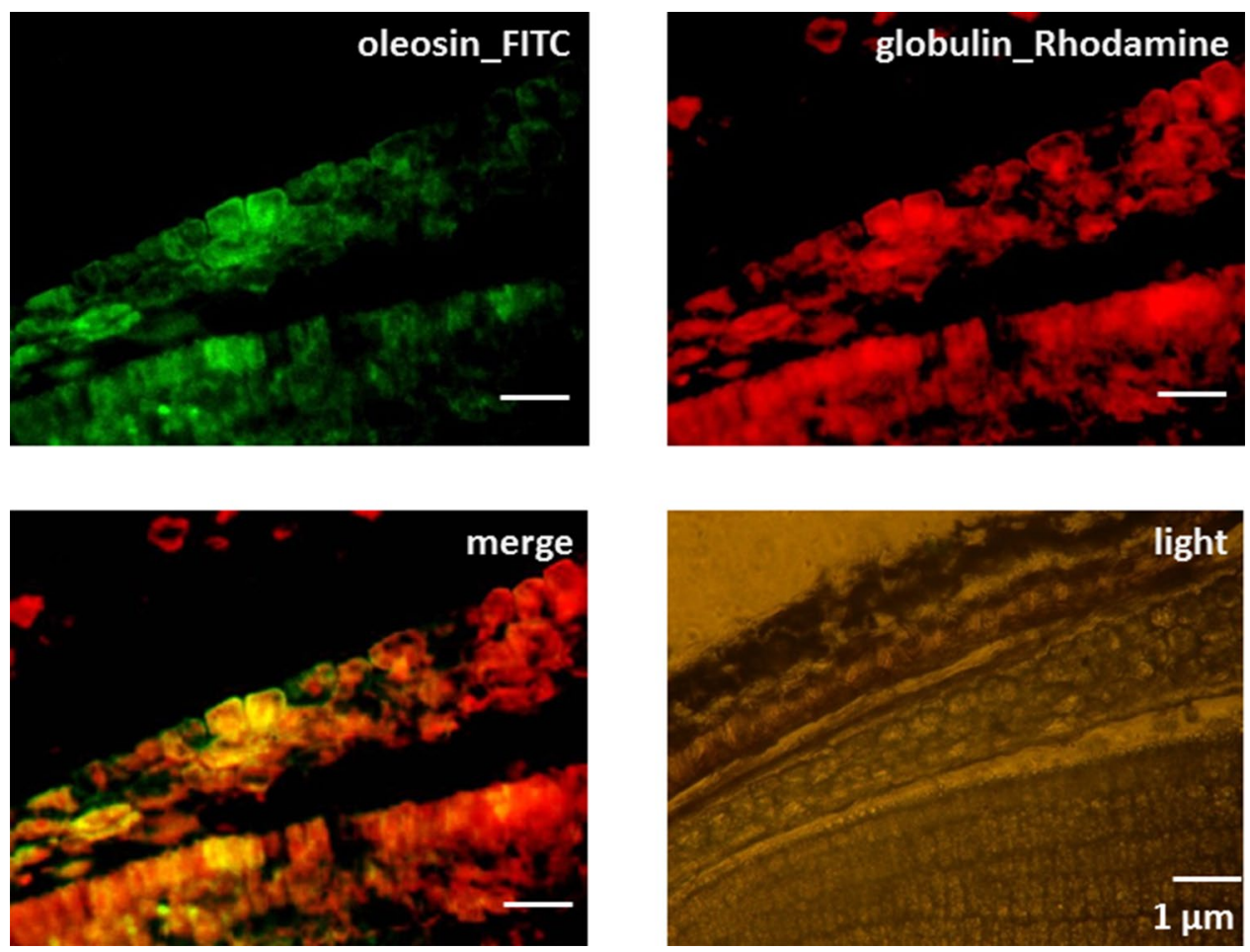

Fig. 5 Localization of 11S globulins in native lipid droplets.

Native lipid droplets, isolated as described in "Isolation and purification of lipid droplets" in the Materials and Methods were prepared to study the localization of $11 \mathrm{~S}$ globulins. Native lipid droplets treated with CTAB were incubated with polyclonal rabbit anti-soybean $11 \mathrm{~S}$ globulin as the primary antibody and with FITC-conjugated goat anti rabbit $\operatorname{IgG}$ as the secondary antibody. Scale bars show $5 \mu \mathrm{m}$
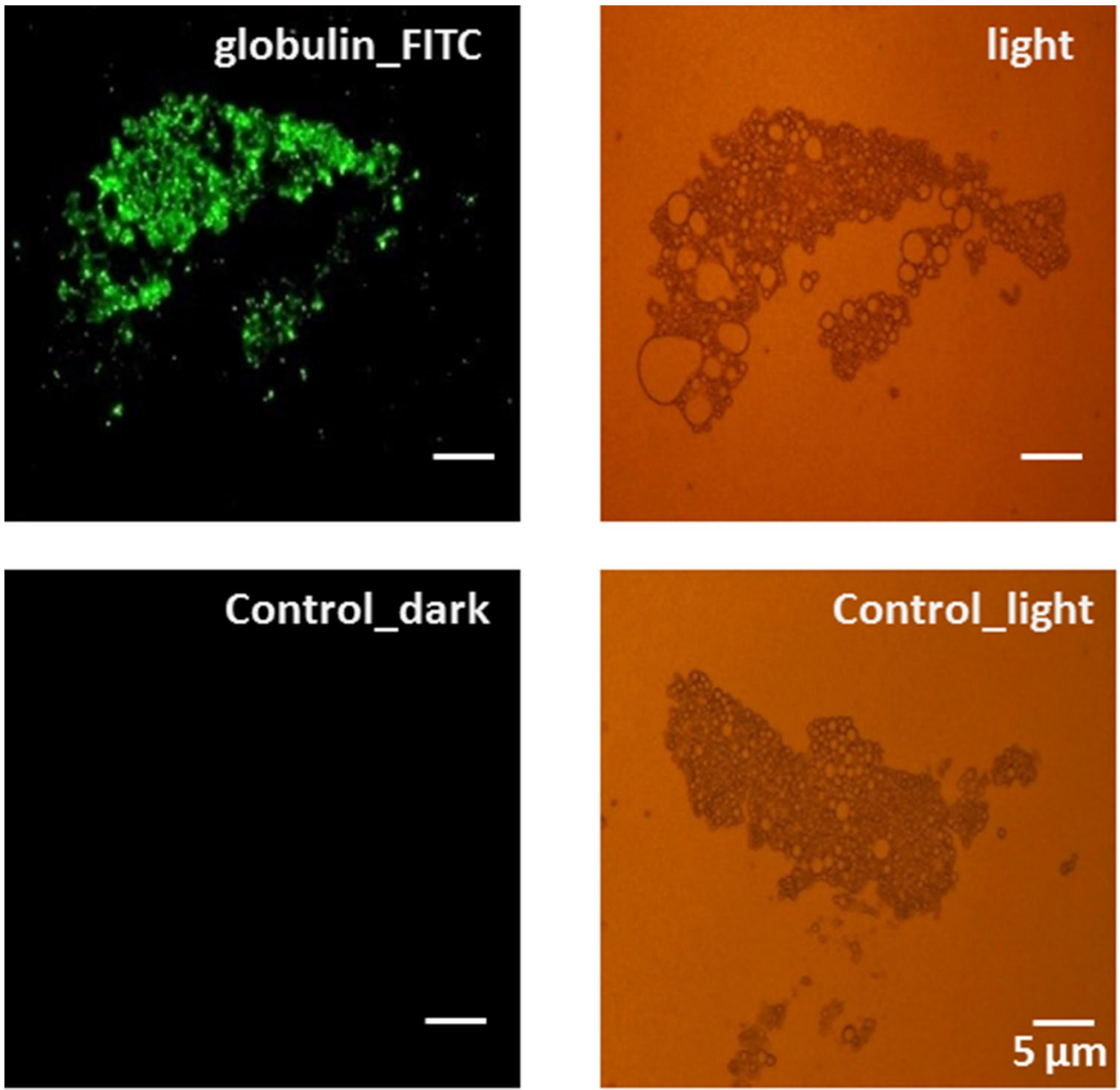
Fig. 6 Two-dimensional electrophoresis of sample II treated with acid phosphatase. The positions of oleosin proteins are shown by an arrow. Left panel (with acid phosphatase), right panel (without acid phosphatase)

\section{+ acid phosphatase -acid phosphatase}

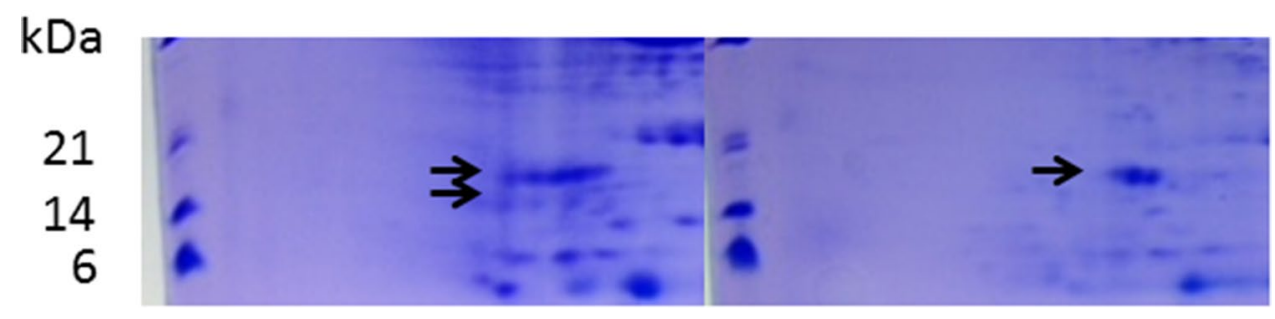

sesame oil, but also might dynamically function through interactions with other organelles [22, 23].

The existence of heat shock proteins in lipid droplets is important in the transportation of proteins. Three kinds of $70-\mathrm{kDa}$ heat shock protein, one $60-\mathrm{kDa}$ heat shock protein, and two kinds of low molecular weight, 17-kDa and $18-\mathrm{kDa}$, heat shock proteins were detected as lipid droplet proteins. It is thought that the three major proteins, oleosin, caleosin, and steroleosin, are coincidentally transported to lipid droplets in the formation of lipid droplets from the ER [4]. It is necessary to reconsider the transportation of lipid droplet components. Total proteins from the ER as well as lipid droplets were also investigated by LC-MS/MS. However, oleosin, caleosin, and steroleosin proteins were not confirmed in the ER (data not shown), although the storage proteins $7 \mathrm{~S}$ globulin, $11 \mathrm{~S}$ globulin, and $2 \mathrm{~S}$ albumin were detected in the ER.

Six spots of 7S globulin, 27 spots of $11 \mathrm{~S}$ globulin, and one spot of $2 \mathrm{~S}$ albumin, which are authentically localized in protein bodies, were identified as lipid droplet proteins in this study. Although all six spots of $7 \mathrm{~S}$ globulin were a mature type, 24 of 27 spots in $11 \mathrm{~S}$ globulin were precursor types (Fig. 3; Table 1). These suggested that $11 \mathrm{~S}$ globulins were processed and transported from the ER to protein bodies after synthesis in the ER as $11 \mathrm{~S}$ globulin precursors, are different from 7S globulins. Although both 7 and 11 $\mathrm{S}$ globulins are synthesized as precursor types in the ER, processed during transportation, and finally stored as mature types in protein bodies [24], differences between 7 and $11 \mathrm{~S}$ globulins were observed at the transportation and processing steps. The differences might reflect their retention times in the ER. The retention time of $11 \mathrm{~S}$ globulin precursors in the ER might be longer than that of 7S globulin precursors, because $11 \mathrm{~S}$ globulins are formed with disulfide bonds, whereas 7S globulins do not have disulfide bonds. Although we cannot explain the reason why differences between $11 \mathrm{~S}$ globulin and 7S globulin precursors occurred at the processing and transportation steps from the ER to protein bodies, it is conceivable that $7 \mathrm{~S}$ globulin precursors and $11 \mathrm{~S}$ globulin precursors are transported through different processing steps to protein bodies to prevent mixing between $7 \mathrm{~S}$ globulin precursors and $11 \mathrm{~S}$ globulin precursors $[25,26]$.
What is the process of $11 \mathrm{~S}$ globulin precursor accumulation in lipid droplets? There are two possibilities. One is $11 \mathrm{~S}$ globulin precursors are incorporated into lipid droplets during transportation from the ER to protein bodies after synthesis in the ER as 11S globulin precursors. However, considering that $11 \mathrm{~S}$ globulins are transported directly from the ER to the Golgi apparatus, it is difficult to consider this possibility. The second is that $11 \mathrm{~S}$ globulin precursors are incorporated into lipid droplets while lipid droplets are being formed. For the formation of lipid droplets, three hypotheses were considered (Fig. 1). (1) Lipid droplets bud off toward the cytosol (Fig. 1a). (2) Lipid droplets are formed and leave behind a gap in the ER membrane, and afterwards the gap closes immediately (Fig. 1b). In both a and b, when triacylglycerols (TAGs) accumulate between the leaflets of the ER membrane and a critical size is reached, lipid droplets might bud off from the ER membrane of the leaflet of the cytosol side (Fig. 1a) or lipid droplets might be excised from the ER membrane of the leaflets of the cytosol side and lumen side (Fig. 1b). (3) The formation of TAG-filled secretory vesicles undergo remodeling of the ER-derived bilayer to yield a monolayer from the ER membrane of the leaflet on the cytosol side, covering lipid droplets. The ER membrane from the leaflet of the lumen side is enfolded in the lipid droplet (Fig. 1c). From the point of view that 24 of 27 spots in 11S globulin were precursor types (Table 1) and that they were inside the lipid droplets (Fig. 5), lipid droplets are likely to be formed as in the model of Fig. 1c.

Furthermore, the model in Fig. 1c made it possible to explain the fact that protein disulfide isomerase, calreticulin, BiP, and elongation factor, as marker proteins of the $\mathrm{ER}$, were found in lipid droplets.

Acknowledgements We would like to thank to Drs. K. Yamada and K. Masuda (Toyama University) for providing sesame materials, and Dr. S. Utsumi (Kyoto University) for providing polyclonal antibodies against soybean 11S globulin.

\section{Compliance with Ethical Standards}

Conflict of interest The authors declare that there are no conflicts of interest. 
Ethical Approval All procedures performed in studies involving animals were in accordance with the ethics committee of Kinki University.

Open Access This article is licensed under a Creative Commons Attribution 4.0 International License, which permits use, sharing, adaptation, distribution and reproduction in any medium or format, as long as you give appropriate credit to the original author(s) and the source, provide a link to the Creative Commons licence, and indicate if changes were made. The images or other third party material in this article are included in the article's Creative Commons licence, unless indicated otherwise in a credit line to the material. If material is not included in the article's Creative Commons licence and your intended use is not permitted by statutory regulation or exceeds the permitted use, you will need to obtain permission directly from the copyright holder. To view a copy of this licence, visit http://creativecommons.org/licenses/by/4.0/.

\section{References}

1. Rogalski M, Carrer H (2011) Engineering plastid fatty acid biosynthesis to improve food quality and biofuel production in higher plants. Plant Biotechnol J 9:554-564. https://doi.org/10.1 111/j.1467-7652.2011.00621.x

2. Frandsen GI, Mundy J, Tzen JTC (2001) Oil bodies and their associated proteins, oleosin and caleosin. Physiol Plant 112:301-307. https://doi.org/10.1034/j.1399-3054.2001.1120301.x

3. Lin L-J, Tai SSK, Peng C-C, Tzen JTC (2002) Steroleosin, a sterol-binding dehydrogenase in seed oil bodies. Plant Physiol 128:1200-1211. https://doi.org/10.1104/pp.010928

4. Tzen JTC, Cao Y-Z, Laurent P, Ratnayake C, Huang AHC (1993) Lipids, proteins and structure of seed oil bodies from diverse species. Plant Physiol 101:267-276. https://doi.org/10.1104/ pp.101.1.267

5. Murphy DJ, Cummins I, Kang AS (1989) Synthesis of the major oil-body membrane protein in developing rapeseed (Brassica napus) embryos. Integration with storage-lipid and storage-protein synthesis and implications for the mechanism of oil-body formation. Biochem J 258: 285-293. https://doi.org/10.1042/bj2580285

6. Kohlwein SD, Veenhuis M, van der Klei ID (2013) Lipid droplets and peroxisomes: key players in cellular lipid homeostasis or a matter of fat-store 'em up or burn' em down. Genetics 193:1-50. https://doi.org/10.1534/genetics.112.143362

7. Lambert N, Freedman RB (1985) The latency of rat liver microsomal protein disulphide-isomerase. Biochem J 228: 635-645. https ://doi.org/10.1042/bj2280635

8. Kishikawa A, Inoue M, Tarutani S, Okunishi T, Ina R, Yoshida K, Takada N, Yoshida M (2018) Screening of sesame cultivars with scant albumins by an immunological approach. Food Biotechnol 32: 273-285. https://doi.org/10.1080/08905436.2018.1519445

9. Laemmli UK (1970) Cleavage of structural proteins during the assembly of the head of bacteriophage T4. Nature 227:680-685

10. Tzen JTC, Peng CC, Cheng DJ, Chen ECF, Chiu JMH (1997) A new method for seed oil body purification and examination of oil body integrity following germination. J Biochem 121: 762-768. https://doi.org/10.1093/oxfordjournals.jbchem.a021651

11. Chen ECF, Tai SSK, Peng C-C, Tzen JTC (1998) Identification of three novel unique proteins in seed oil bodies of sesame. Plant Cell Physiol 39:935-941. https://doi.org/10.1093/oxfordjournals. pcp.a029457

12. Tnani H, Lopez I, Jouenne T, Vicient CM (2011) Protein composition analysis of oil bodies from maize embryos during germination. J Plant Physiol 168:510-513. https://doi.org/10.1016/j.jplph .2010.08.020

13. Nguyen HM, Baudet M, Cuine S, Adriano J-M, Barthe D, Billon E, Bruley C, Beisson F, Peltier G, Ferro M, Li-Beisson Y
(2011) Proteomic profiling of oil bodies isolated from the unicellular green microalga Chlamydomonas reinhardtii: with focus on proteins involved in lipid metabolism. Proteomics 11:4266-4273. https://doi.org/10.1002/pmic.201100114

14. Gidda SK, Park S, Pyc M, Yurchenko O, Cai Y, Wu P, Andrews DW, Chapman KD, Dyer JM, Mullen RT (2016) Lipid dropletassociated proteins (LDAPs) are required for the dynamic regulation of neutral lipid compartmentation in plant cells. Plant Physiol 170:2052-2071. https://doi.org/10.1104/pp.15.01977

15. Hom PJ, James CN, Gidda SK, Kilaru A, Dyer JM, Mullen RT, Ohlrogge JB, Chapman KD (2013) Identification of a new class of lipid droplet-associated proteins in plants. Plant Physiol 162:1926-1936. https://doi.org/10.1104/pp.113.222455 pp 113. 222455

16. Lopez-Ribera I, Paz JLL, Repiso C, Garcia N, Miquel M, Hernandez ML, Martinez-Rivas JM, Vicient CM (2014) The evolutionary conserved oil body associated protein OBAP1 participates in the regulation of oil body size. Plant Physiol 164:1237-1249. https:// doi.org/10.1104/pp.113.233221

17. Gao Q, Goodman JM (2015) The lipid droplet-a well-connected organelle. Front Cell Dev Biol 3:1-12. https://doi.org/10.3389/ fcell.2015.00049

18. Katavic V, Agrawal GK, Hajduch M, Harris SL, Thelen JJ (2006) Protein and lipid composition analysis of oil bodies from two Brassica napus cultivars. Proteomics 6:4586-4598. https://doi. org/10.1002/pmic.200600020

19. Jolivet P, Acevedo F, Boulard C, d'Andre'a S, Faure J-D, Kohli A, Nesi N, Valot B, Chardot T (2012) Crop seed oil bodies: from challenges in protein identification to an emerging picture of the oil body proteome. Proteomics 13:1836-1849. https://doi. org/10.1002/pmic.201200431

20. Liu H, Wang C, Chen F, Shen S (2015) Proteomic analysis of oil bodies in mature Jatropha curcas seeds with different lipid content. J Proteomics 113:403-414. https://doi.org/10.1016/j.jprot .2014 .10 .013

21. Zhi Y, Taylor MC, Campbell PM, Warden AC, Shrestha P, El Tahchy A, Rolland V, Vanhercke T, Petrie JR, White RG, Chen W, Singh SP, Liu Q (2017) Comparative lipidomics and proteomics of lipid droplets in the mesocarp and seed tissues of chinese tallow (Triadica sebifera). Front Plant Sci 8:1339-1358. https:// doi.org/10.3389/fpls.2017.01339

22. Dinis AM, Coutinho AP (2009) Interaction of lipid bodies with other cell organelles in the maturing pollen of Magnolia $\times$ soulangeana (Magnoliaceae). Protoplasma 238:35-46. https://doi. org/10.1007/s00709-009-0071-6

23. Farese JRV, Walther TC (2009) Lipid droplets finally get a little RESPECT. Cell 139:855-860. https://doi.org/10.1016/j. cell.2009.11.005

24. Fukasawa T, Hara-Nishimura I, Nishimura M (1988) Biosynthesis, intracellular transport and in vitro processing of $11 \mathrm{~S}$ globulin precursor proteins of developing castor bean endosperm. Plant Cell Physiol 29:339-345. https://doi.org/10.1093/oxfordjournals. pcp.a077499

25. Hsia Y-H, Yu C-J, Li W-T, Hsieh J-F (2015) Coagulation of $\beta$ conglycinin, glycinin and isoflavones induced by calcium chloride in soymilk. Sci Rep 5:13018. https://doi.org/10.1038/srep13018

26. Morita K, Shimoyamada M (2013) Proposal of mechanism of the freeze-thaw fractionation of $7 \mathrm{~S}$ and $11 \mathrm{~S}$ globulins in soymilk. Food Chem 140:39-43. https://doi.org/10.1016/j.foodc hem.2013.01.103

Publisher's Note Springer Nature remains neutral with regard to jurisdictional claims in published maps and institutional affiliations. 